\title{
The Values of Maccera Tappareng Ceremony In Buginese Society at Wajo Regency (Local Culture Analysis)
}

\author{
Muhajir \\ Pendidikan Bahasa Inggris, Fakultas Sastra, Universitas Muslim Indonesia \\ muhajir.sastra@umi.ac.id
}

\begin{abstract}
This paper discussed what values exist in the ceremony of Maccera Tappareng in Wajo Regency. This is intended to express all kinds of values in the ritual system of Maccera Tappareng especially in Wajo Regency. This paper used qualitative method with descriptive approach and the data collection was done by using triangulation are interview, observation and documents. The results of this study shows the ceremony of Maccera Tappareng as local culture gives information about the values still exist in this culture in preserving the ceremony of Maccera Tappareng in Wajo regency.
\end{abstract}

Keywords: Values, Ceremony, Maccera Tappareng

\begin{abstract}
Abstrak
Makalah ini membahas nilai-nilai apa yang ada dalam upacara Maccera Tappareng di Kabupaten Wajo. Penelitian ini dimaksudkan untuk mengekspresikan semua jenis nilai dalam sistem ritual Maccera Tappareng terutama di Kabupaten Wajo. Penelitian ini menggunakan metode kualitatif dengan pendekatan deskriptif dan pengumpulan data dilakukan dengan menggunakan triangulasi yaitu wawancara, observasi dan dokumen. Hasil penelitian ini menunjukkan upacara Maccera Tappareng sebagai budaya lokal memberikan informasi tentang nilai-nilai masih ada dalam budaya ini dalam melestarikan upacara Maccera Tappareng di Kabupaten Wajo,
\end{abstract}

Keywords: Values, Ceremony, Maccera Tapparang

\section{Introduction}

Every society has culture with all its sharp, include force values and vital idea that forms idea sharp from each culture universally, culture value definitively as an idea aspect that created as abstract concepts which lives in large part of resident in a society about something that must be considered important and valuable in life (Aholiab, 2013; Rahayu, 2000). Referring to that meaning, cultural value as an abstract concept is certainly not able to get sensory perception. Nevertheless, the existence of cultural value itself can always be expressed through its reflection that is exposed in normative behavior system either in society through its supporter. Thus, cultural value is actually a vital idea that becomes the source or orientation of attitude and behavior system in the social culture life context.

According to Rahim, (2015) that the meaning of cultural values is very im- portant. The statement indicates that in the society life of human being a kind of improvement on production method either the distribution is evenly distributed of whole production result. But, it's far more important a fulfillment effort on ideas, concept and values which are inspired, obeyed and applicated together by its supporter society (Setyaningrum, Budi, Diah, Naomi., 2018). It means, that network of glorious culture values system that grow and develop in region, include, the glorious culture values which traditionally has grown and developed in Buginese society life in Wajo necessary to be investigated and expressed, to strengthen and enrich the potency of nation culture.

Buginese society in Wajo land is one of religious social unity that historically has accepted Islamic religion as formal (legal) religion of kingdom since 1610 (Rahkmat, 1981). Yet, in culture social life, their behavior is still always pre-Islamic belief sys- 
tem that oriented toward veneration (worship) of gods. By this case Patunru (1983) adapted motto, creation of Arung Saontare Latiringeng Totaba that sounded that "Naposalamakenggi to Wajoe Malempue Rigau Salae, Metau Ridewata Seuwae, Masiri Ripadataunna". That adaptation indicates that terms of Dewata (Buginese Language) which means Dewa (Gods) include one of religion term that has been known for before Islam religion got into Wajo region, in fact it is used for interpreting name Allahu Ahad or Al Ahad (the one and the only god).

The belief of Dewata is applicated by worship form through system of traditional ritual ceremony, called Maccera Tappareng (worship to lake gods) (Rahkmat, 1981). This ritual include kind of bift dedication ritual to the gods (Dewa) whom considered (regarded as) master the waters' territorial resident Tempe Lake, and conducted in a hereditary particularly by of fisherman society in that area. According to tradition at the local (place), Maccera Tappareng ceremony is held once a year in matter of catching fish's period (season) at Tempe Lake. Executing of the ceremony pervaded by attitude, action, and symbolic words that has cultural meaning. Cultural meaning that given toward ritual symbols itself describe existence of glorious values network system that since long time ago had grown developed in society who supported it around waters territorial at Tempe Lake (Depdikbud, 1994).

Realizing about uniqueness and specification the ceremony of Maccera Tappareng, that is loaded with values of glorious culture, culture inheritance from forefathers (ancestors) of Wajo people in the past periode. Therefore, the problem put forward in this paper is what values exist in the ceremony of Maccera Tappareng in Wajo regency. This is intended to discuss and express all kinds of values in the ritual system of Maccera Tappareng especially in Wajo regency.

utur literal dan nonliteral.(Wijana,1996, 2011).

\section{Method}

As etymology, the ceremony of Maccera Tappareng is compound two words which is found in Buginese language, namely Maccera and Tappareng (Rahayu, 2000). Maccerra is a verb infinitive that come from "cera" that has a meaning blood, and if we put prefix in front of infinitive (maccera) which are meaning given blood or worship. And the word of "tappareng" is Buginese language that has meaning is lake. So, if translate into English that the meaning of Maccera Tappareng is a worship of blood to Tempe Lake.

Refers to etiologies above, so as terminology term, Maccera Tappareng is contained a meaning as one of ceremony which formed in offering worship such as blood of animals to abstract creature, which considered that area is sacred. Mattulada (1999), said that beliefs of abstract creature like "Dewa Air" (water's lord) it's not only is a personification that created by the traditional though pattern. While Alisyahbana (1988), said all of the things that have a soul is belief of dynamism system. Based on statement above, so in the past time, the ceremony of Maccera Tappareng for Wajo society as one of respecting form to "Dewa air" (water's lord). However, Wajo society has receive Islam as legal religion, believable system to Dewata is moved in respecting to Haidir prophet, (god's prophet) as lord of especially in Tempe territorial

\section{Result and Disucussion \\ 3.1 The Purpose of Maccera Tappareng Ceremony}

The ceremony of Maccera Tappareng in Tempe Lake is held in glad and secret situation, where Wajo society has participate in collective to celebrate that ceremony (Mattulada, 1991). Through this way can support solidarity feel in Wajo society, especially they live as fisherman and they hope will get two aspects are (i) through this ceremony, the fisherman in Tempe sub district hope to get a god harvest in this year, (ii) through this ceremony, it hoping for fisherman which done the activity in territorial Tempe lake will safety and avoided from great disaster. Based on aspect above, so it can conclude that the purpose of Maccera Tappareng ceremony to improve solidarity feel on Dewata (water's lord) in order 
they got many livelihood and also the safety in all seasons in this year.

\subsection{The Values Related with the Time of Ceremony}

\subsubsection{Science Value}

One of types related traditional knowledge and science with the traditional ceremony execution in Tempe sub district is knowledge about time. Traditionally, local society until now still defended the cultural heritage of their ancestor about the time that is thought well, beside certain assumed bad with quality. According to result of field research, most of society citizen still trust about the good time and the bad time to begin one activity. Referring to that, they ever try to unite the opinion in order to determine the time which is thought well to conduct or to begin the ceremony of Maccera Tappareng.

The process of election and determining the time that assumed well to begin the ceremony activity, Wajo society in Tempe sub district traditionally used three concepts of cultural science are (i) knowledge about bad and good month in a year, (ii) knowledge of good and bad day, (iii) knowledge of good and bad time in a day.

\subsubsection{Religion Value}

In determining of time to do Maccera Tappareng ceremony in Tempe subdistrict can be adapted with their cultural knowledge about existence of bad and good time (Fauzi Nurdin. 2009). Referring to that, so in knowledge concept about this time itself consists of religion value, where Wajo society is include of Pakkaja society (fishermen) believe in existence of a supernatural power that mastering every time circulation.

Based on the believable system, all fishermen try to avoid the certain times to conduct an activity, because they trust the existence of certain supernatural power that dominate the universe at that moment, while that power does not support the activity of human life work (Hasanuddin, 2017). On the contrary, at the certain times for instance time assumed valuable of Mallisek or Tuo, they conduct the work activity with assumption that supernatural power that mastering universe at that moment is deity of divisor livelihood. From the description, that in determining of time to conduct the ceremony Maccera of Tappareng at least concerning with religion value orienting to local society assumption, about existence of good deity beside virulent deity or about existence of disturber deity and also the existence of benefactor deity. Those all according to culture knowledge which is wide and profound enough for Pakkaja society, to get the optimal result in their work activities as fishes catcher in Tempe lake.

\subsubsection{Economic Value}

According to cultural knowledge conception in Wajo society about the existence of empty valuable time beside the other time in assigning value to contain, so, to determine the time to conduct the ceremony of Maccera Tappareng in Tempe subdistrict is conducted when valuable of mallisek. That stipulating time of Mallisek is conducted with an expectation, that at season catch the fish that underway; they will get fish as possible. Based on the description above, to choose the time for conduct the ceremony of Maccera Tappareng also contain the economic value, in order to support the Pakkaja society to effort as maximum and also to get the optimal result. In modern society life of course in using of time beside the job discipline will be arranged in such a manner in order can support the improvement efficiency of job and will support the result of their productivity. Perhaps, the principle like this has not been realized by traditional society, but from the reality of their productivity Pakkaja society used this principle, to increase their spirit in working, they believe Mallisek time and believe that will get good result.

Out of the problem of rather differing time use system between modern society and simple society which live as Pakkaja (fisherman), by from this research result can be affirmed that in certain time that become one of Maccera Tappareng ceremony element consisted also of economic value

di atas 50 persen, yaitu 60 persen.

\subsection{The Valuess Related with the Place of}




\section{Ceremony}

Ceremony of implementation in Maccera Tappareng, especially phase of offerings devoting in the form of buffalo head to the water deity that contained with religion values which is up to now supported by most society especially Pakkaja society (fisherman) Tempe in Subdistrict, it is based on several fundamental basic as follows:

1. Offerings material to water deity cannot be done its devoting in any place but it have to in certain place assumed precisely according to guide of the soothsayer (Pawang).

2. Place selected and decided for the offerings devoting place assumed eerie and holy, its location reside in middle of Tempe Lake.

3 . Eeriness and holiness of that place considered as a sign, that the place is residential center of deity who dominates totality territorial water of Tempe Lake.

4. Deity who dominates the water that also assumed master entire potency of natural resources hidden in Tempe Lake included fishes. Referring to that, offerings have to be dedicated directly to the resident of water deity, in order the activity of fishes capture in the year running can obtain optimal result.

The description above can be indicated that the place selected and determine become the location of offerings devoting contain the religion value. The deity of water can only accept in this case offering devoting assumed if that offering is dedicated as worship to that place. This means also, that religion value refer to shape materialization to the water of deity which rides in the place of Maccera Tappareng ceremony.

The place of ceremony not only contains the religion value, but also contains the economic value. The economic value assumed that Pakkaja society in Tempe Subdistrict that offerings have to be dedicated to the deity of water in certain place to represent its residency center. This aim that devoting can soften his heart, so that all fishermen get the result as much as possible in a year. From the brief description, we can see that in determining the location to dedi- cate the offerings not only contain the religion value, but partaking also contain the economic value, especially to increase the result of product and productivity of fish for all Pakkaja in Tempe Subdistrict.

\subsection{The Valuess Related with the Equip- ments of Ceremony}

The implementation of Maccera Tappareng ceremony in Tempe sub district practically is collective ceremony that involved a whole group or local society component. Referring to that can be expressed the existence of two values of cultural type with the equipment of ceremony that is the value of solidarity and religion value. The values solidarity for example in preparing the equipment of ceremony, where the material is collected from contribution of society citizen, government, generous and other sources. That is a prove, without cooperation between all society component so the ceremony of Maccera Tappareng, specially in preparation and levying of raw material will not go well.

Besides social solidarity value at process of levying raw material that collected from all contributor, the values solidarity it can be seen in preparation the place of offerings substance that is Lawasuji. In making of Lawasuji the members of Wajo society in Tempe sub district do the cooperation voluntarily. In substance and equipments of ceremony contained also the solidarity value. This value supported the spirit of cooperation for whole society component, even in preparing of raw material and also in preparing Lawasuji, as place to keep the offerings substance to be dedicated. The religious value, which contained in the offerings and equipments of ceremony Maccera Tappareng as follows:

1. In believable system of Islam pre, either from believable system of animism and also dynamism of chicken's egg considered as a curio, because it can hatch a chick, even that egg encircled with the husk. In consequence, Wajo society uses the chicken's egg as offerings to the deity of water.

2. Siri Pinang is one of types offering element assumed as a substance of hobby Sang Dewa (deity of waters). 
3. The head of buffalo, assumed by society as most high valuable animal shares. The head of buffalo is devoting to the deity of water.

\subsection{The Valuess Related with the Atti- tude and Action}

All attitude and action of ceremony contained with the religious value (Brennan., Kumaran., Cantrell, R. \& Spranger, M., 2014). In phase of offerings devoting in the middle of Tempe Lake and whole of ceremony competitor have to behave kept quiet and seriously in following all ceremony phase. This circumstance show the their adherence and respect to their deity of water. The action of participant ceremony usually has a good attitude, beware and seriously in moving or lifting substance of offerings and also indicate have cold feet and their surrender ness to the deity of water. And then the action of master ceremony in burning frankincense showed of sight to begin the process of communications between the deity and human being through the soothsayer. While the incense smoke to the space, the soothsayer as master of ceremony read the magic formula and incantation. In the incantation and prayer indicated of application and expectation of human being to the deity of water, so that all Pakkaja given safety and livelihood in order to get good result in their effort fish arrest. It indicated the attitude surrender, bow, and adherence of human being to supernatural power that is deity of water.

Based on the description above, it's right what Ufie, (2006) view, that incantation formula is translation from ducky of desire human being which wisdom of utterance in order support to natural strength. Related with this view, Pakkaja society in Tempe sub district until now still rely on the incantation and prayer as one of way to request the deity of water, In order they get result which abundance at season catch. In reading of pray and incantation, by itself the soothsayer needs the special knowledge and science about that. Except that, so they will not conduct their duty well. Because of that, in attitude, action and utterance of ceremony contained also special science related with communication method to the deity of water.

\subsection{The Values Related with the Absten- tion or Prohibition of Ceremony}

The types of abstention in this ceremony that recorded in this research relative minimum, even though can be description that religious value related with some abstention are; (i) prohibition ask or pray in front of the boat which bringing offerings. This abstention contain the value religion, that the trespasser and also society as religion union less respect to the deity water, (ii) each participant of ceremony prohibit to move the oar during master of ceremony reading the pray and incantation. In this case contained religious value that intrinsically expected seriousness for whole participant ceremony, (iii) participant of ceremony prohibit do the activity of fish arrest before conducted an offerings devoting to the deity of water. In this abstention there is impress that Pakkaja to conduct the fish arrest before offerings in the middle of Tempe Lake, so that indicate prioritize the will of deity bless.

\section{Conclusion}

Based on the explanation above, the ceremony of Maccera Tappareng in Wajo society contains traditional culture values as follows:

1. Science value related with the ceremony of Maccera Tappareng consist of (i) astronomy science is important in determining of time that assumed a good or bad time to conduct the ceremony of Maccera Tappareng, (ii) traditional knowledge, especially for the master ceremony that called Sanro for communication with Dewata (deity of water).

2. Religious value in the ceremony of Maccera Tappareng contained religious value which orientation to worship the supernatural power which called Poanganroanna Tapparengnge. This god stayed in the middle of Tempe Lake.

3. Economic value, in this case, Wajo society as executor in this ceremony belief that with conduct this ceremony could increase their production in cached fish season. 


\section{Reference}

Agus, Ufie. 2006. Mengonstruksi Nilainilai Kearifan Lokal (Local Wisdom) dalam Pembelajaran Muatan Lokal sebagai Upaya Memperkokoh Kohesi Sosial (Studi Deskriptif Budaya Niolilieta Masyarakat Adat Pulau Wetang Kabupaten Maluku Barat Daya, Propinsi Maluku). Jurnal Pendidikan dan Pembelajaran. Vol. 23, No. 2. Hal. 80-89.

Brennan, M., Kumaran, M., Cantrell, R., \& Spranger, M. 2014. The Importance of Incorporating Local Culture into Community Development. Ifas Extension. University of Florida.

Daeng, Patunru, Abdurazak, 1983. Sejarah Wajo. Ujung Pandang Yayasan Kebudayaan Sulawesi Selatan.

Depdikbud, 1994. Upacara-upacara Tradisional dalam Kaitannya dengan Peristiwa Alam dan Kepercayaan. Proyek Investigasi dari Dokumen Sejarah Nilai Tradisional.

Fauzi Nurdin. 2009. Integralisme Islam dan Nilai-Nilai Filosofis Budaya Lokal pada Pembangunan Propinsi Lampung. Jurnal UNISIA, Vol. XXXII. No. 71. Hal. 81-97.

Hasanuddin. 2017. Nilai dan Karakter Budaya Indonesia. Conference Paper. Kebudayaan sebagai Strategi Penguatan Jati Diri Bangsa, diselenggarakan Balai Pelestarian Nilai Budaya Aceh.

Matulada. 1999. Kesukubangsaan dan Negara Kebangsaan di Indonesia. Jurnal Antropologi Indonesia. Vol. 58.

Mattulada. 1991. Manusia dan Kebudayaan Bugis-Makassar dan Kaili di Sulawesi. Jurnal Antropologi Indonesia. Vol. 48.

Salam, Rahayu, 2000. Sejarah dan Nilai Tradisional Sulawesi Selatan.

Direktorat Jenderal Kebudayaan Dep. P\&K Balai Kajian Sejarah \& Nilai Tradisional.

Setyaningrum, Budi, Diah, Naomi. 2018. Budaya Lokal di Era Global. Jurnal Ekspresi Seni, Vol.20, No 2. Hal. 102112.

Subagya, Rahkmat, 1981. Agama Asli In- donesia. Sinar Harapan dan Yayasan Loka Caraka.

Watloly Aholiab. 2013. Cermin Eksistensi Masyarakat Kepulauan dalam Pembangunan Bangsa. Jakarta: Intimedia Cipta.

Yunus, Rahim, Abd. 2015. Nilai-Nilai Islam dalam Budaya dan Kearifan Lokal (Konteks Budaya Bugis). Jurnal Rihla. Vol. II. No. 1. Hal. 1-12. 